STUDIA I PRACE WYDZIAŁU NAUK EKONOMICZNYCH I ZARZĄDZANIA nr 41, t. 2

\title{
Maryla Bieniek-Majka*
}

doktorantka Uniwersytetu Ekonomicznego w Poznaniu

\section{ZMIANY NA RYNKU OWOCÓW I WARZYW W POLSCE PO AKCESJI DO UNII EUROPEJSKIEJ}

\begin{abstract}
Streszczenie
W artykule przedstawiono kształtowanie się wartości chrakteryzujących rynek owoców i warzyw. Omówiono kształtowanie się wielkości i intensywności produkcji, wskazano relację popytowo-cenową na owoce i warzywa oraz strukturę obrotów w handlu zagranicznym. Zwrócono uwagę na fakt wpływu sytuacji politycznej, która spowodowała zachwianie na rynku owoców i warzyw w 2014 roku. Przedstawione dane pozwalają stwierdzić, że ostatnia dekada dla producentów owoców i warzyw była sprzyjająca, czego efektem był rozwój tego sektora.
\end{abstract}

Słowa kluczowe: owoce i warzywa, rozwój, rynek

\section{Wprowadzenie}

W pierwszej dekadzie członkostwa Polski w Unii Europejskiej sektor owocowo-warzywny rozwijał się dynamicznie, co było zasługą zarówno czynników wynikających z koniunktury rynkowej, silnej pozycji konkurencyjnej, jak i znacznych strumieni pieniężnych przekazanych na ten rynek w ramach funduszy europejskich $^{1}$. Celem niniejszego artykułu jest przedstawienie zmian na polskim rynku

* E-mail:maryl.b@wp.pl

1 T. Filipiak, M. Maciejczak, Uwarunkowania rozwoju sektora owoców $i$ warzyw w Polsce w latach 20042007, Roczniki Nauk Rolniczych, seria G, t. 95, z. 2, PAN, Warszawa 2008, s. 97. 
owoców i warzyw, jakie miały miejsce po akcesji do Unii Europejskiej. Na podstawie danych opublikowanych przez GUS oraz IERiGŻ za pomocą metod analizy szeregów czasowych przedstawiono zmiany wielkości produkcji i areału przeznaczonego na uprawę warzyw i owoców. Zaprezentowano kształtowanie się popytu i cen na owoce i warzywa. Za pomocą współczynnika korelacji Pearsona określono relację popytowo-cenową. Zwrócono uwagę na strukturę i bilans handlu zagranicznego. Na podstawie wyników z przeprowadzonych badań można stwierdzić, że Polska stała się liczącym producentem o stabilnym udziale w produkcji warzyw i bardziej dynamicznym, rosnącym udziale w produkcji owoców w Unii Europejskiej. W badanym okresie zauważa się większy przyrost wielkości produkcji niż ekstensyfikację. Świadczą o tym szybciej rosnące wielkości zbiorów owoców i warzyw niż areał ziemi przeznaczony na ich uprawę. Na szczególne podkreślenie zasługuje produkcja krzewów owoców jagodowych (przede wszystkim borówki amerykańskiej) oraz uprawy warzyw pod osłonami. Gospodarowanie i planowanie produkcji ułatwiały producentom stabilne ceny, popyt i rozwój wymiany międzynarodowej.

\section{Produkcja owoców i warzyw w Polsce na tle Unii Europejskiej}

Polska jest znaczącym producentem owoców i warzyw w Unii Europejskiej (rysunek 1). Udział produkcji warzyw w produkcji generowanej przez kraje unijne jest stabilny i kształtuje się na poziomie 8,45-9,46\%. Udział produkcji owoców jest bardziej dynamiczny i charakteryzuje się tendencją rosnącą. W badanym okresie kształtował się na poziomie 4,91-10,82\%. Należy podkreślić, że na niski wynik zanotowany w 2007 roku miały wpływ niesprzyjające warunki agrometeorologiczne.

Na podstawie danych zawartych w tabeli 1 można stwierdzić, że polscy producenci zajęli liczącą się pozycję na unijnym rynku owoców i warzyw, szczególnie wśród krajów nowo przyjętych w struktury UE po 2004 roku. W produkcji unijnej udział polskiej produkcji warzyw kształtował się na poziomie około 9\%, a udział polskiej produkcji owoców około 9-11\%. 


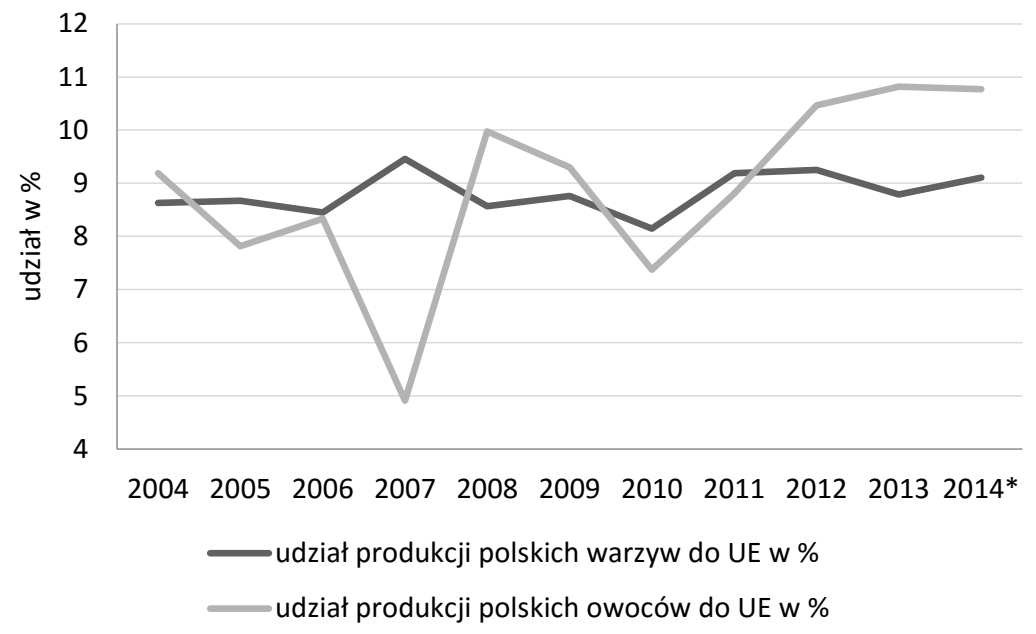

Rysunek 1. Udział produkcji polskich owoców i warzyw na tle produkcji w Unii Europejskiej w latach 2004-2014*

* Dane niepełne.

Źródło: opracowanie własne na podstawie Rynek owoców $i$ warzyw. Stan i perspektywy, „Analizy Rynkowe” 2006, nr 29; 2008, nr 33; 2011, nr 38; 2013, nr 42; 2014, nr 44; 2014, nr 45.

Tabela 1. Produkcja warzyw i owoców w Polsce w latach 2004-2014 na tle Unii Europejskiej

\begin{tabular}{|c|c|c|c|c|c|c|c|c|c|c|}
\hline \multirow[b]{2}{*}{ Rok } & \multicolumn{5}{|c|}{ Produkcja warzyw (mln ton) } & \multicolumn{5}{|c|}{ Produkcja owoców (mln ton) } \\
\hline & 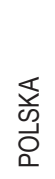 & 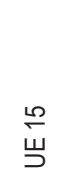 & 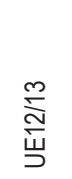 & 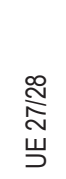 & 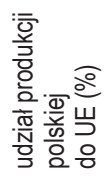 & 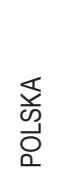 & 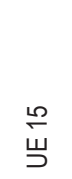 & 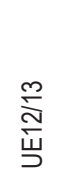 & $\begin{array}{l}\stackrel{\infty}{N} \\
\underset{\sim}{J}\end{array}$ & 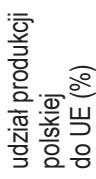 \\
\hline 2004 & 5,8 & 53,7 & 13,5 & 67,2 & 8,63 & 3,5 & 31,6 & 6,5 & 38,1 & 9,19 \\
\hline 2005 & 5,6 & 52,5 & 12,1 & 64,6 & 8,67 & 2,9 & 31,7 & 5,4 & 37,1 & 7,82 \\
\hline 2006 & 5,3 & 50,2 & 12,5 & 62,7 & 8,45 & 3,2 & 33 & 5,4 & 38,4 & 8,33 \\
\hline 2007 & 5,9 & 50,5 & 11,9 & 62,4 & 9,46 & 1,7 & 31,3 & 3,3 & 34,6 & 4,91 \\
\hline 2008 & 5,4 & 51,5 & 11,5 & 63,0 & 8,57 & 3,8 & 30,9 & 7,2 & 38,1 & 9,97 \\
\hline 2009 & 5,8 & 54,4 & 11,8 & 66,2 & 8,76 & 3,6 & 32,1 & 6,6 & 38,7 & 9,30 \\
\hline 2010 & 5,1 & 52,4 & 10,2 & 62,6 & 8,15 & 2,7 & 31,0 & 5,6 & 36,6 & 7,38 \\
\hline 2011 & 5,8 & 52,2 & 10,9 & 63,1 & 9,19 & 3,4 & 32,5 & 6,1 & 38,6 & 8,81 \\
\hline 2012 & 5,7 & 51,0 & 10,6 & 61,6 & 9,25 & 3,8 & 29,8 & 6,5 & 36,3 & 10,47 \\
\hline 2013 & 5,3 & 49,9 & 10,4 & 60,3 & 8,79 & 4,1 & 31,0 & 6,9 & 37,9 & 10,82 \\
\hline $2014^{*}$ & 5,6 & 50,5 & 11,0 & 61,5 & 9,11 & 4,2 & 32,0 & 7,0 & 39,0 & 10,77 \\
\hline
\end{tabular}

* Dane niepełne.

Źródło: opracowanie własne na podstawie Rynek owoców $i$ warzyw. Stan i perspektywy, „Analizy Rynkowe” 2006, nr 29; 2008, nr 33; 2011, nr 38; 2013, nr 42; 2014, nr 44; 2014, nr 45. 
Na rodzimym rynku udział produkcji owoców w towarowej produkcji rolniczej w badanym okresie (rysunek 2) kształtował się na poziomie od 5,2\% w 2010 do 7,6\% w 2011 roku i charakteryzował się większą dynamiką niż produkcja warzyw. Udział produkcji warzyw był bardziej stały, kształtował się na poziomie $6,2 \% \mathrm{w} 2005$ i osiągnął poziom $8,9 \% \mathrm{w} 2013$ roku.

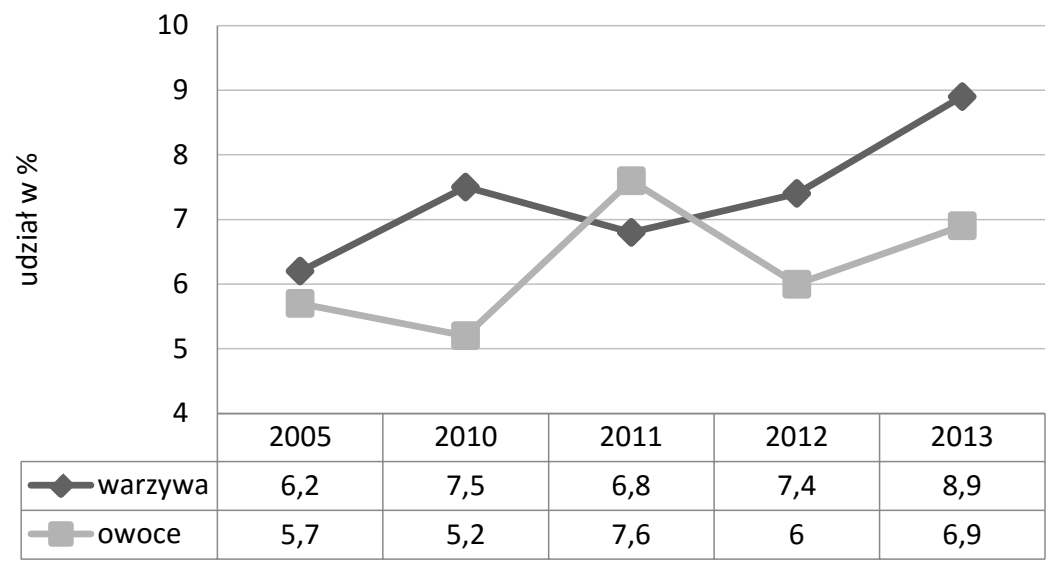

Rysunek 2. Udział owoców i warzyw w towarowej produkcji rolniczej w latach 2005-2013 (ceny bieżące).

Źródło: opracowanie własne na podstawie danych z Rocznika statystycznego rolnictwa 2014, GUS, Warszawa 2014, s. 181.

Należy zauważyć, że udział produkcji warzyw charakteryzuje się tendencją rosnącą niemającą odzwierciedlenia w ilości produkcji per capita, wielkości zbiorów warzyw gruntowych czy wielkości areału przeznaczonego na ich uprawę.

Jak wynika z rysunku 3, wielkość produkcji warzyw per capita charakteryzuje się tendencją malejącą, a wielkość produkcji owoców tendencją rosnącą. Wielkość zbiorów jest zależna m.in. od powierzchni gruntów przeznaczonych na ich uprawę. 


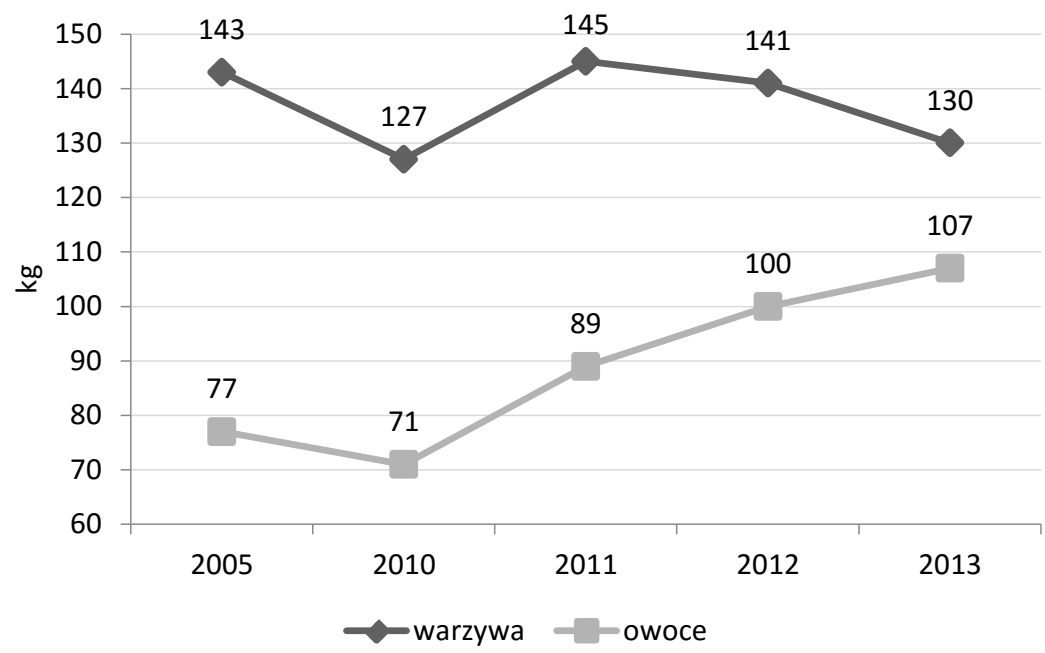

Rysunek 3. Produkcja warzyw i owoców w kg per capita w latach 2005-2013.

Źródło: opracowanie własne na podstawie danych z Rocznika statystycznego rolnictwa 2014, GUS,

Warszawa 2014, s. 187.

\section{Zmiany w powierzchni upraw i zbiorów owoców i warzyw w Polsce}

O intensyfikacji produkcji świadczą dane zawarte w tabeli 2 i 3. Przyrost wielkości zbiorów zarówno warzyw, jak i owoców w 2013 roku w porównaniu do 2005 był większy niż przyrost wielkości gruntów przeznaczonych na ich uprawę.

Tabela 2. Powierzchnia uprawy i zbiory owoców w latach 2005-2013

\begin{tabular}{|l|c|c|c|c|c|c|}
\hline \multicolumn{1}{|c|}{ Wyszczególnienie } & 2005 & 2010 & 2011 & 2012 & 2013 & $\begin{array}{c}\text { Zmiana } \\
\text { 2013/2005 } \\
(\%)\end{array}$ \\
\hline $\begin{array}{l}\text { Powierzchnia upraw drzew } \\
\text { owocowych (ha) }\end{array}$ & 254108 & 275854 & 292681 & 291750 & 274230 & 108 \\
\hline $\begin{array}{l}\text { Zbiory owoców z drzew } \\
\text { tys. ton) }\end{array}$ & 2421,6 & 2217,5 & 2883,8 & 3285,8 & 3521,6 & 145 \\
\hline $\begin{array}{l}\text { Powierzchnia upraw } \\
\text { krzewów owocowych, } \\
\text { plantacji jagodowych } \\
\text { l leszczyny (ha) }\end{array}$ & 132882 & 134249 & 135875 & 140061 & 150469 & 113 \\
\hline $\begin{array}{l}\text { Zbiory owoców z krzewów } \\
\text { owocowych i plantacji } \\
\text { jagodowych oraz leszczyny } \\
\text { (tys. ton) }\end{array}$ & 499,9 & 526,1 & 530,7 & 557,4 & 606,8 & 121 \\
\hline
\end{tabular}

Źródło: opracowanie własne na podstawie danych z Rocznika statystycznego rolnictwa 2014, GUS, 
Na podstawie powyższych danych można zauważyć, że powierzchnia uprawy drzew owocowych w 2013 roku w porównaniu do 2005 wzrosła o niespełna 8\%, a wielkość zbiorów owoców o 45\%. Ekstensyfikacja produkcji i intensyfikacja zbiorów może świadczyć o doinwestowaniu producentów ${ }^{2}$. Dysponując większymi środkami, producenci mogli unowocześnić, zmechanizować proces produkcji, zakupić więcej środków ochrony roślin i doprowadzić do maksymalizacji zbiorów. Powierzchnia upraw krzewów owocowych, plantacji jagodowych i leszczyny charakteryzuje się większą ekstensyfikacją. Powierzchnia upraw wzrosła w badanym okresie o $13 \%$, a zbiory o $21 \%$, jednak na uwagę zasługuje fakt, że największą dynamiką charakteryzują się owoce ujęte w typologii GUS jako „pozostałe”, czyli np. borówki amerykańskie 3 . W badanym okresie zanotowano wzrost o $85 \%$ powierzchni upraw i o $72 \%$ wielkości zbiorów. Można domniemać, że wielkość zbiorów będzie rosła ze względu na wieloletność roślin i przesunięcie w czasie owocowania od zasadzenia.

Tabela 3. Powierzchnia uprawy i zbiory warzyw w latach 2005-2013

\begin{tabular}{|l|c|c|c|c|c|c|}
\hline \multicolumn{1}{|c|}{ Wyszczególnienie } & 2005 & 2010 & 2011 & 2012 & 2013 & $\begin{array}{c}\text { Zmiana } \\
\text { 2013/2005 } \\
(\%)\end{array}$ \\
\hline $\begin{array}{l}\text { Powierzchnia upraw } \\
\text { gruntowych (tys. ha) }\end{array}$ & 222 & 158,7 & 178,9 & 175,5 & 142,1 & 64 \\
\hline $\begin{array}{l}\text { Zbiory warzyw gruntowych } \\
\text { tys. ton) }\end{array}$ & 4785 & 4189 & 4803 & 4553 & 4004 & 84 \\
\hline $\begin{array}{l}\text { Powierzchnia upraw } \\
\text { pod osłonami (tys. m²) }\end{array}$ & 54293 & 48906 & 51481 & 53060 & 61206 & 113 \\
\hline $\begin{array}{l}\text { Zbiory warzyw z upraw } \\
\text { pod osłonami (tys. ton) }\end{array}$ & 673 & 689 & 772 & 877 & 982 & 146 \\
\hline
\end{tabular}

Źródło: opracowanie własne na podstawie danych z Rocznika statystycznego rolnictwa 2014, GUS, Warszawa 2014, s. 202-203.

Produkcja warzyw mimo rosnącego udziału w towarowej produkcji rolniczej zmienia swoją strukturę. Udział produkcji warzyw gruntowych spada, a rośnie udział warzyw uprawianych pod osłonami. Powierzchnia przeznaczona pod uprawę warzyw gruntowych w 2013 roku w porównaniu do 2005 spadła aż o 36\%, wielkość zbiorów w tej sytuacji tylko o 16\%. Jest to dowód na zwiększenie inten-

2 Do 31.03.2015 wypłacono 7078472 tys. zł z tytułu pomocy finansowej w ramach wspólnej organizacji rynku owoców i warzyw, z czego 6746 865,4 tys. zł na pokrycie części kwalifikowanych kosztów inwestycji.

3 Borówki amerykańskie stają się coraz chętniej produkowanym owocem, ich eksport sięga około 80-90\% produkcji. 
syfikacji produkcji zarówno tej gruntowej, jak i pod osłonami. Wielkość zbiorów warzyw uprawianych pod osłonami w 2013 roku w porównaniu do 2005 wzrosła aż o $46 \%$, gdy wielkość gruntów do produkcji pod osłonami wzrosła o $13 \%$.

\section{Relacje popytowo cenowe na rynku owoców i warzyw w Polsce}

W badanym okresie przeciętne spożycie owoców i ich przetworów w gospodarstwach domowych w kilogramach na 1 mieszkańca kształtowało się od 39,48 kg w 2011 do 46,92 kg w 2004 roku. Należy zauważyć, że istnieje korelacja pomiędzy wielkością popytu a ceną.

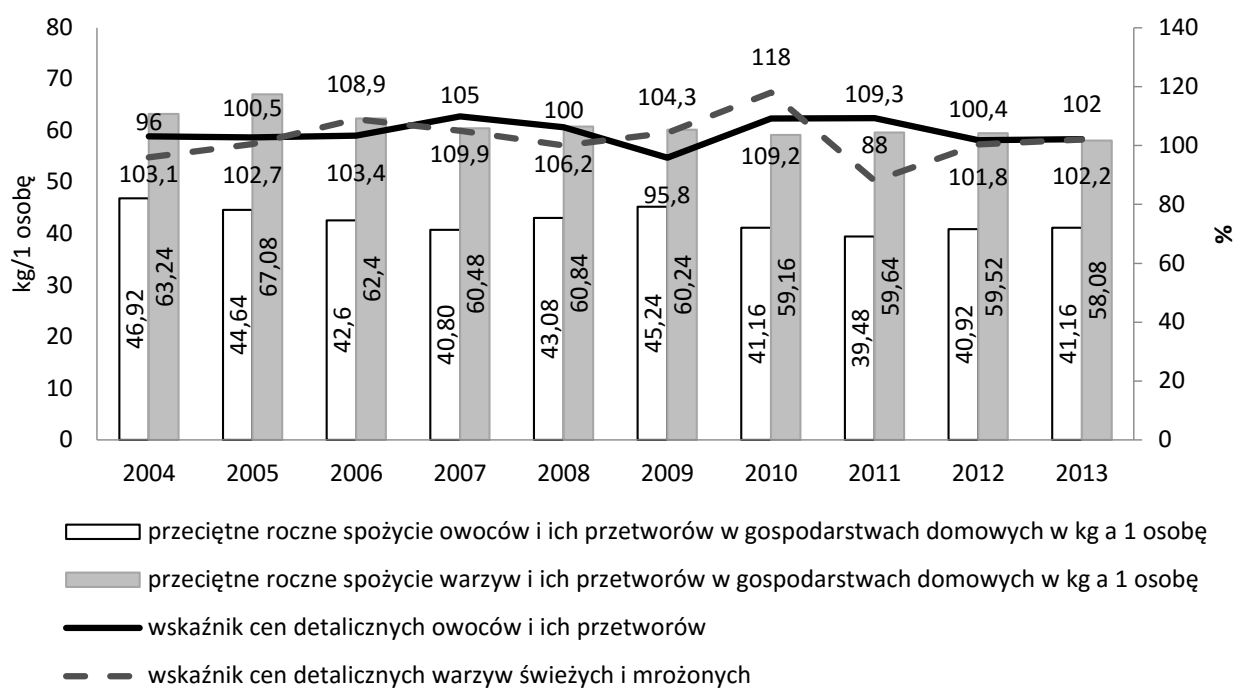

Rysunek 4. Przeciętne roczne spożycie warzyw i owoców oraz wskaźnik cen detalicznych warzyw i owoców w latach 2004-2013.

Źródło: opracowanie własne na podstawie Rynek owoców $i$ warzyw. Stan i perspektywy, „Analizy Rynkowe” 2006, nr 29; 2008, nr 33; 2011, nr 38; 2013, nr 42; 2014, nr 44; 2014, nr 45.

W 2011 roku wiosenne przymrozki spowodowały spadek podaży i wzrost cen, co miało odzwierciedlenie w wielkości popytu na owoce. Przeciętne spożycie warzyw i ich przetworów było bardziej stabilne i kształtowało się w badanym okresie od 67,08 kg na osobę w 2005 do 58,08 kg w 2013 roku. Można zauważyć, że przeciętne spożycie warzyw w kilogramach na osobę spada. Spowodowane jest to m.in zmianą preferencji asortymentu. Polscy konsumenci spożywają mniej warzyw ciężkich, np. kapusty, a więcej lżejszych, np. sałaty. Na podstawie 
danych z rysunku 4 można stwierdzić, że popyt na warzywa był nieelastyczny cenowo - spadek cen w 2011 roku nie spowodował wzrostu spożycia, a wzrost cen w 2006 roku spowodował nieznaczny spadek popytu. Bardziej wrażliwy jest popyt na owoce. Można zauważyć, że wraz ze spadkiem cen owoców wielkość popytu na nie wzrosła (2009). W latach 2006-2007 i 2010-2011 wzrost cen spowodował spadek wielkości spożycia owoców. Kierunek zależności relacji popytowo-cenowych jest zgodny z założeniem prawa popytu, gdyż współczynnik determinacji jest ujemny dla owoców i warzyw, jednak dla owoców wynosi $-0,32$, a dla warzyw tylko $-0,04$, co potwierdza, że cena ma większy wpływ na decyzję zakupu owoców, a na zakup warzyw w nieznacznym stopniu.

\section{Handel zagraniczny owocami i warzywami}

Handel zagraniczny polskimi owocami i warzywami po akcesji do Unii Europejskiej charakteryzował się tendencją rosnącą. Wartość eksportowanych owoców w 2013 w porównaniu do 2004 roku wzrosła o 159\%, a warzyw o 142\%. Wartość importowanych owoców w analogicznym okresie wzrosła o 132\%, a warzyw aż o 245\% (rysunek 5). W 2014 roku pomimo niepełnych danych zauważa się spadek eksportu i importu. Zmniejszenie importu może wynikać ze zmniejszenia zapotrzebowania na zagraniczne owoce i warzywa w związku z nadwyżkami rodzimych produktów na rynku, które są konsekwencją wprowadzenia w okresie zbiorów (sierpień) embarga na rynek rosyjski. Rynek wschodni miał istotny i rosnący udział w polskim eksporcie. Sytuacja zmusiła producentów do zdywersyfikowania kierunków handlowych i przestawienia oferty. Zachwiania na rynku w mniejszym stopniu dotyczą eksportu przetworów owoców i warzyw (brak embarga) niż świeżych produktów.

Ma to odzwierciedlenie w wysokości salda obrotów warzywami i owocami. Mimo zachwiania sytuacji można spodziewać się nadal dodatniego salda obrotów. Należy zauważyć, że nieprzerwanie od 2011 roku notuje się dodatnie saldo obrotów w handlu zagranicznym. Na podstawie danych zawartych w tabeli 4 można stwierdzić, że na wynik ten ma wpływ wysoka wartość eksportowanych przetworów owocowych i warzywnych, gdyż saldo w obrocie surowymi owocami i warzywami jest ujemne. Istotne jest utrzymanie, a nawet wzmocnienie pozycji Polski na zagranicznych rynkach, gdyż w sytuacji nasycenia się rynku wewnętrznego eksport staje się głównym motorem dalszego rozwoju sektora ${ }^{4}$.

\footnotetext{
4 L. Jabłońska, D. Olewnicki, Rozwój i znaczenie sektora ogrodniczego w Polsce w ostatnim półwieczu, Roczniki Naukowe Ekonomii Rolnictwa i Rozwoju Obszarów Wiejskich, t. 101, z. 3, Warszawa 2014, s. 34.
} 


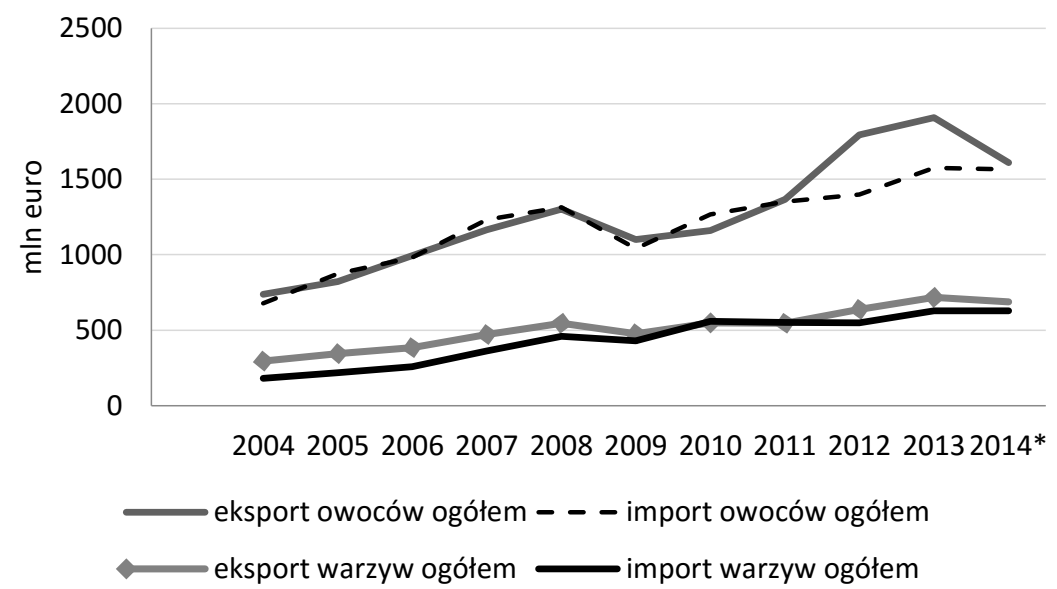

Rysunek 5. Wartość obrotów handlu zagranicznego owocami, warzywami i ich przetworami (mln euro) w latach 2004-2014.

Źródło: opracowanie własne na podstawie Rynek owoców i warzyw. Stan i perspektywy, „Analizy Rynkowe” 2006, nr 29; 2008, nr 33; 2011, nr 38; 2013, nr 42; 2014, nr 44; 2014, nr 45.

Tabela 4. Wartość salda obrotów handlu zagranicznego owocami, warzywami i ich przetworami (mln euro) w latach 2004-2014

\begin{tabular}{|l|r|r|r|r|r|r|r|r|r|r|r|r|}
\hline Wyszczególnienie & 2004 & 2005 & 2006 & 2007 & 2008 & 2009 & 2010 & 2011 & 2012 & 2013 & $2014^{*}$ & $\begin{array}{r}\text { Zmiana } \\
2013 / \\
2004\end{array}$ \\
\hline $\begin{array}{l}\text { Saldo obrotów } \\
\text { owoców }\end{array}$ & 59,3 & $-51,8$ & 12,8 & $-68,1$ & $-11,4$ & 58,1 & $-107,4$ & 14,7 & 394,4 & 332,3 & 45 & 5,60 \\
\hline $\begin{array}{l}\text { Saldo obrotów } \\
\text { owoce świeże }\end{array}$ & -316 & -394 & -468 & -566 & $-626,6$ & $-362,3$ & $-477,5$ & $-473,8$ & $-278,5$ & -305 & -455 & 0,96 \\
\hline $\begin{array}{l}\text { Saldo obrotów } \\
\text { przetwory } \\
\text { owocowe }\end{array}$ & 375,5 & 342 & 480,7 & 497,9 & 615,2 & 420,4 & 370,1 & 488,5 & 672,9 & 637,3 & 500 & 1,70 \\
\hline $\begin{array}{l}\text { Saldo obrotów } \\
\text { warzyw }\end{array}$ & 113,7 & 127 & 126,5 & 109,2 & 88,5 & 45,6 & $-11,7$ & $-3,3$ & 90,9 & 88,7 & 59 & 0,78 \\
\hline $\begin{array}{l}\text { Saldo obrotów } \\
\text { warzywa świeże }\end{array}$ & $-16,9$ & $-1,3$ & $-23,5$ & $-33,7$ & $-73,4$ & $-94,8$ & $-152,8$ & $-145,2$ & $-105,4$ & $-158,8$ & -168 & 9,40 \\
\hline $\begin{array}{l}\text { Saldo obrotów } \\
\text { przetwory } \\
\text { warzywne }\end{array}$ & 130,6 & 129 & 150 & 142,9 & 161,9 & 140,4 & 141,1 & 141,9 & 196,3 & 247,5 & 227 & 1,90 \\
\hline
\end{tabular}

*Dane nieostateczne.

Źródło: opracowanie własne na podstawie Rynek owoców $i$ warzyw. Stan i perspektywy, „Analizy Rynkowe” 2006, nr 29; 2008, nr 33; 2011, nr 38; 2013, nr 42; 2014, nr 44; 2014, nr 45. 


\section{Podsumowanie}

Ostatnia dekada dla producentów owoców i warzyw była sprzyjająca. W latach 2004-2013 w produkcji unijnej udział polskiej produkcji owoców i warzyw był rosnący i stabilny. O rozwoju sektora może świadczyć fakt intensyfikacji i ekstensyfikacji produkcji zarówno owoców, jak i warzyw. Na uwagę zasługuje także fakt rosnącego udziału produkcji owoców jagodowych i produkcji warzyw pod osłonami. Popyt oraz ceny na owoce i warzywa, a także ich przetwory w badanym okresie był stabilny, co ułatwiało producentom gospodarowanie i podejmowanie decyzji inwestycyjnych w tym sektorze. Rozwojowi sektora sprzyjała również polityka unijna, która w ramach programu Wspólnej Polityki Rolnej przekazywała środki na ten rynek. Polscy producenci szansę tę wykorzystali i doinwestowali sektor. Dzięki zwiększeniu możliwości konkurencyjnych wzrastało znaczenie Polski na arenie międzynarodowej, o czym świadczą wyniki obrotu międzynarodowego do 2014 roku. Należy jednak zwrócić uwagę, że uwarunkowania polityczne mają odzwierciedlenie w sytuacji na rynku owoców i warzyw. Nadal istnieje pilna potrzeba rozwoju rynku , a dalszy rozwój sektora owoców i warzyw w Polsce będzie zależeć od budowania trwałych przewag konkurencyjnych na rynku, dostosowania oferty do potrzeb konsumentów, umiejętności wykorzystania dostępnych form pomocy, głównie z Unii Europejskiej, oraz kooperacji i zaangażowania wszystkich uczestników sektora ${ }^{6}$. Istotna jest także integracja na rynku, wzmocnienie promocji polskich produktów i dywersyfikacja oferowanych produktów i odbiorców.

\section{Literatura}

Filipiak T., Maciejczak M., Uwarunkowania rozwoju sektora owoców $i$ warzyw w Polsce w latach 2004-2007, Roczniki Nauk Rolniczych, seria G, t. 95, z. 2, PAN, Warszawa 2008.

Jabłońska L., Olewnicki D., Rozwój i znaczenie sektora ogrodniczego w Polsce w ostatnim pótwieczu, Roczniki Naukowe Ekonomii Rolnictwa i Rozwoju Obszarów Wiejskich, t. 101, z. 3, Warszawa 2014.

Jakość polskich borówek jest ceniona na catym świecie, http://www.sadyogrody.pl/ owoce/101/jakosc_polskich_borowek_jest_ceniona_na_calym_swiecie,521.html.

F. Kapusta, Rynek owoców w Polsce w okresie przedakcesyjnym i po akcesji do Unii Europejskiej, „Ekonomia XXI Wieku" 2014, nr 3(3), s. 21.

6 T. Filipiak, M. Maciejczak, Uwarunkowania rozwoju sektora owoców i warzyw..., s. 108. 
Kapusta F., Rynek owoców w Polsce w okresie przedakcesyjnym i po akcesji do Unii Europejskiej, „Ekonomia XXI Wieku” 2014, nr 3(3).

Rynek owoców i warzyw. Stan i perspektywy, „Analizy Rynkowe” 2006-2014, nr 29-45. Rocznik statystyczny rolnictwa, GUS, Warszawa 2014.

\title{
CHANGES ON THE FRIUT AND VEGETABLE MARKET IN POLAND AFTER JOINING THE EUROPEAN UNION
}

\begin{abstract}
The article explains the development of fruit and vegetable market features. It says how the production has developed and intesified, how demand and prices influence the fruit and vegetable market and the structure of turnover in external trade. It is stated that the last dacade was favourable for the fruit and vegetable producers and that is why the sector has developed. The article focuses on the influence of political situation on the marketthe imbalance of the situation in 2014 year.
\end{abstract}

Translated by Maryla Bieniek-Majka

Keywords: fruit, vegetables, development, market

JEL codes: Q02, Q11 
